\section{Pulmonary function abnormalities in non-splenectomized and splenectomized adult hemoglobin $E / \beta$-thalassemia patients and their correlation with pulmonary hypertension}

\author{
Prapaporn Pornsuriyasak, ${ }^{1}$ \\ Kulanee Vongvivat, ${ }^{1}$ \\ Khanchit Likittanasombat, ${ }^{2}$ \\ Thitiporn Suwatanapongched, ${ }^{3}$ \\ Vichai Atichartakarn ${ }^{4}$ \\ 'Pulmonary and Critical Care Division, \\ Department of Medicine; ${ }^{2}$ Cardiology \\ Division, Department of Medicine; \\ ${ }^{3}$ Department of Diagnostic and \\ Therapeutic Radiology; ${ }^{4}$ Hematology \\ Division, Department of Medicine, \\ Ramathibodi Hospital, Mahidol \\ University, Bangkok, Thailand
}

\section{Abstract}

The effect of splenectomy on pulmonary function test (PFT) and pulmonary hypertension $(\mathrm{PH})$ in thalassemia remains unclear. We aimed to investigate PFT and their association with $\mathrm{PH}$ in patients with hemoglobin $\mathrm{E} / \beta$-thalassemia stratified by their splenic status Thirteen splenectomized patients (SP) and 12 non-splenectomized patients (NSP) were compared regarding to the PFT abnormalities and PH (mean pulmonary artery pressure from right-heart catheterization $\geq 25 \mathrm{mmHg}$ or estimated systolic pulmonary artery pressure from echocardiography $\geq 40 \mathrm{mmHg}$ ). Eleven (84\%) SP and 9 (75\%) NSP had restrictive impairment (RI). Of these, more patients having severe RI in SP than in NSP ( 8 vs $2, \mathrm{P}=0.035$ ). FVC and $\mathrm{PaO}_{2}$ were lower in SP than in NSP ( $66 \pm 15 \%$ vs $77 \pm 12 \%, \mathrm{P}=0.043$, and $79.38 \pm 1.6$ $\mathrm{mmHg}$ vs $98.83 \pm 6.2 \mathrm{mmHg}, \mathrm{P}<0.001$, respectively). Residual volume was higher in SP than in NSP $(78 \pm 17 \%$ vs $64 \pm 15 \%, \mathrm{P}=0.036)$. Seven (54\%) SP who developed $\mathrm{PH}$ had a longer time interval between splenectomy and the onset of PH than those who did not $(17 \pm 4.9$ years $v s$ $9.8 \pm 6.1$ years, $\mathrm{P}=0.04$ ). In conclusion, greater severity of extrapulmonary restrictive impairment and hypoxemia were more common in SP. These patients developed PH as a late complication unrelated to hypoxemia and PFT parameters.

\section{Introduction}

Previous studies have reported pulmonary dysfunction in patients with $\beta$-thalassemia (Thal); mostly with restrictive impairment (RI) in patients being transfusion-dependent ${ }^{1-11}$ and also in non-transfusion dependent patients. $^{12-14}$ Other pulmonary abnormalities consist of small airway obstruction, ${ }^{12,15}$ impairment of diffusion capacity, ${ }_{16,17}$ arterial hypoxemia, ${ }^{16,18}$ and pulmonary hypertension (PH).$^{19-21}$ Blood transfusion and iron chelation therapy for thalassemia disease in Thailand are usually not as intensive as in Western countries due to limited resources. This could have some effects on pulmonary dysfunction in these patients. The effect of splenectomy on the pulmonary functions remains unclear and their association with PH has not yet been reported. We aimed to investigate the pulmonary function abnormalities, and their association with $\mathrm{PH}$ in hemoglobin $\mathrm{E} / \beta$-Thal patients stratified by their splenic status.

\section{Materials and Methods}

This retrospective study was performed with the approval of our institutional ethics committee. A computer search of our hospital databases between January 2000 and December 2007 identified 42 patients with E/ $\beta$-Thal, diagnosed based on hematologic data and thalassemia genotype. Out of the 42 patients, we excluded 17 patients who had no pulmonary function tests (PFT). Twenty-five patients had PFT performed approximately within 6 months apart from the echocardiography or right heart catheterization (RHC). The final study group consisted of 25 patients, whom were further classified into 2 groups, i.e., splenectomized patients (SP) and non-splenectomized patients (NSP). The medical records were reviewed for demographic data (age, gender, height, and body weight), smoking history, age at splenectomy performed, and laboratory data including hemoglobin, platelet count, nucleated red blood cells (nRBC), reticulocyte count, serum alanine aminotransferase (ALT), and serum ferritin level. An experienced chest radiologist retrospectively reviewed chest radiographs for the presence or absence of extramedullary hematopoiesis (i.e., abnormal soft-tissue masses along the paravertebral areas and/or ribs), thalassemic bone changes, and cardiomegaly.

\section{Pulmonary function tests}

All PFT measurements were performed using Vmax system ${ }^{\circledR}$ (Sensor Medics, Yorba Linda, CA, USA). Spirometry including forced
Correspondence: Prapaporn Pornsuriyasak, Division of Pulmonary and Critical Care, Department of Medicine, 272 Ramathibodi Hospital, Rama 6 Road, Bangkok 10400, Thailand. Tel. +66.2.2011629 ext. 19/+66.8.1.6465390 Fax: +66.2.2011629.

E-mail address: pprapaporn@gmail.com

Key words: pulmonary function tests, thalassemia, splenectomy, pulmonary hypertension.

Acknowledgments: we would like to thank Prof. Poonkasem Charoenpan and Ms. Supattra Kiawwan for assistance in the results of pulmonary function tests, and Ms. Napaporn Archararit for assistance in searching the chest radiographs for review.

Contributions: PP, data collection, data statistical analysis, manuscript drafting; KV, KL, data collection, TS, data interpretation, manuscript critical revision; VA, study design and conception, manuscript critical revision, manuscript final approval.

Conference presentation: $16^{\text {th }}$ Congress of the Asian Pacific Society of Respirology, November $5^{\text {th }}$ 2011, Shanghai, China.

Conflict of interests: the authors declare no potential conflict of interests.

Received for publication: 6 June 2013.

Revision received: 17 October 2013

Accepted for publication: 18 0ctober 2013.

This work is licensed under a Creative Commons Attribution 3.0 License (by-nc 3.0).

CCopyright P. Pornsuriyasak et al., 2013

Licensee PAGEPress, Italy

Thalassemia Reports 2013; 3:e5

doi:10.4081/thal.2013.e5

expiratory volume at 1 second $\left(\mathrm{FEV}_{1}\right)$, forced vital capacity (FVC), forced expiratory flow between $25 \%$ and $75 \%$ of vital capacity $\left(\mathrm{FEF}_{25}\right.$ ${ }_{75 \%}$ ), and measurement of lung volumes, i.e., total lung capacity (TLC), and lung volumes subdivision including residual volume (RV), functional residual capacity (FRC), inspiratory capacity (IC), and expiratory reserve volume (ERV) were recorded. Single-breath diffusing capacity for carbon monoxide $\left(\mathrm{DL}_{\mathrm{CO}}\right), \mathrm{DL}_{\mathrm{CO}}$ value adjusted for hemoglobin concentration, and $\mathrm{DL}_{\mathrm{CO}}$ adjusted for alveolar volume $\left(\mathrm{DL}_{\mathrm{CO}} \mathrm{NA}\right)$ were recorded. The normal reference values for pulmonary function tests were based on the Crapo reference equation. ${ }^{22,23}$ Arterial blood gases results performed at the time of PFT measurements were also recorded. The parameters in arterial blood gases including partial pressure of oxygen $\left(\mathrm{PaO}_{2}\right)$ and carbon dioxide $\left(\mathrm{PaCO}_{2}\right)$ were used in the calculation of alveolar-arterial partial pressure of oxygen difference $\left[\mathrm{P}(\mathrm{A}-\mathrm{a}) \mathrm{O}_{2}\right.$ ] based on alveolar gas equation. Arterial hypoxemia was consid- 
ered when $\mathrm{PaO}_{2}$ at room air was $<80 \mathrm{mmHg}$. Obstructive impairment was defined as $\mathrm{FEV}_{1} / \mathrm{FVC}<75 \%$, and $\mathrm{FEV}_{1}<80 \%$. RI was defined as $\mathrm{FEV}_{1} / \mathrm{FVC} \geq 75 \%$ with $\mathrm{FVC} \leq 80 \%$ or $\mathrm{TLC} \leq 80 \%$. Severity of RI was classified based on reduction in TLC (mild, TLC 60-79\%; moderate, TLC 40-59\%; severe, TLC<40\%). Small airway involvement was based on the values of $\mathrm{FEF}_{25}$ $75 \%<60 \%, \mathrm{FEV}_{1} / \mathrm{FVC} \geq 75 \%$, and $\mathrm{FEV}_{1} \geq 80 \%$. In patients having reduced $\mathrm{FVC}$, reduced $\mathrm{FEV}_{1}$, normal $\mathrm{FEV}_{\mathrm{l}} / \mathrm{FVC}$, and reduced $\mathrm{FEF}_{25-75 \%}$, restrictive impairment combined with small airway involvement was considered. $\mathrm{DL}_{\mathrm{Co}}$ was considered low when it was $\leq 70 \%$, otherwise it was considered normal PFT. ${ }^{24}$

\section{Echocardiography and right heart catheterization}

The echocardiography performed within a 6month interval apart from the date of PFT were retrospectively reviewed for the presence of $\mathrm{PH}$ using tricuspid regurgitant velocity to estimate the systolic pulmonary artery pressure. The hemodynamic data from RHC, including systolic pulmonary arterial pressure (SPAP) and mean pulmonary arterial pressure (mean PAP) were recorded at the time of $\mathrm{PH}$ diagnosis. $\mathrm{PH}$ was defined either by echocardiography when estimated systolic pulmonary arterial pressure (eSPAP) was $\geq 40 \mathrm{mmHg}^{25}$ or by $\mathrm{RHC}$ when mean pulmonary arterial pressure (PAP) was $\geq 25 \mathrm{mmHg} .{ }^{26}$

\section{Statistical analyses}

All analyses were performed using SPSS Statistics for Windows version 17. Comparisons of normally distributed continuous data between both groups were made by using independent Student's t-test. Otherwise, MannWhitney U test was used. Categorical data was analyzed by Chi-square or Fisher's exact test. Results were considered statistically different when $\mathrm{P}<0.05$. Pearson's correlation was used to determine the correlation between two continuous variables.

\section{Results}

The final study consisted of $25 \mathrm{E} / \beta$-Thal patients (11 men and 14 women). Thirteen of them were SP, and the remaining 12 patients were NSP. Table 1 shows the characteristics of patients in both groups. Of the $13 \mathrm{SP}$, the patterns of spirometric abnormalities were defined as having RI in 11 (84\%) patients; 2 of 11 patients having RI combined with small airway involvement. Obstructive impairment in 1 (7.7\%) patient and normal spirometry in 1 (7.7\%) patient were noted. Of the 12 NSP, 9 (75\%) had RI; 1 of 9 patients having RI com- bined with small airway involvement; 3 (25\%) patients had normal spirometry. The severity of RI was mild in 10 patients ( 3 of SP and 7 of NSP), and moderate in 10 patients (8 of SP and 2 of NSP). Severe RI was not observed in any cases. Compared with the NSP, a greater proportion of SP had more severity of RI (8 of 11 in SP vs 2 of 9 in NSP, $\mathrm{P}=0.035$ ). The hemoglobin level was not different between the two groups, but platelet count, nRBC count and reticulocyte count were higher in the SP.

Table 2 shows the PFT results, $\mathrm{PaO}_{2}, \mathrm{P}(\mathrm{A}$ - a) $\mathrm{O}_{2}$, and serum ferritin levels in both groups. Arterial hypoxemia was present in 7 of $13 \mathrm{SP}$, but was not present in the NSP $(\mathrm{P}=0.005)$. The $\mathrm{SP}$ group had lower $\mathrm{PaO}_{2}$ than the NSP group $(79.38 \pm 11.6 \mathrm{mmHg}$ vs $98.83 \pm 6.2 \mathrm{mmHg}$, $\mathrm{P}<0.001)$. $\mathrm{P}(\mathrm{A}-\mathrm{a}) \mathrm{O}_{2}$ was greater in the $\mathrm{SP}$ group than in the NSP group $(20.4 \pm 10.5$ vs $6.8 \pm 3.3 \mathrm{mmHg}, \mathrm{P}<0.001)$. Patients with low $\mathrm{DL}_{\mathrm{C} 0}$ were not different between both groups ( 9 of 13 in SP, and 6 of 12 in NSP, $\mathrm{P}=0.4$ ). $\mathrm{PaO}_{2}$ were not correlated with FVC, and TLC but positively correlated with $\mathrm{DL}_{\mathrm{C} 0}(\mathrm{r}=0.44, \mathrm{P}=0.03)$.

Table 1. Characteristics of $E / \beta$-thalassemia patients with and without splenectomy (data are expressed as mean $\pm \mathrm{SD}$ ).

\begin{tabular}{lccc} 
& SP & NSP & P \\
& $\mathrm{N}=13$ & $\mathrm{~N}=12$ & \\
Age (year) & $21.8 \pm 3.3$ & $23.8 \pm 5.1$ & 0.239 \\
Gender M:F & $6: 7$ & $5: 7$ & 0.821 \\
\hline Body weight $(\mathrm{kg})$ & $46 \pm 7.9$ & $50 \pm 6.1$ & 0.171 \\
Height $(\mathrm{cm})$ & $158.4 \pm 7.2$ & $160.4 \pm 8.4$ & 0.522 \\
\hline BMI $\left(\mathrm{kg} / \mathrm{m}^{2}\right)$ & $18.2 \pm 1.8$ & $19.4 \pm 2.0$ & 0.119 \\
Hb (g/dL) & $6.25 \pm 0.9$ & $7.2 \pm 1.5$ & 0.061 \\
\hline Platelet (x10 $/ \mathrm{uL})$ & $652 \pm 198$ & $242 \pm 86$ & $<0.001$ \\
Corrected WBC (x103/uL) & $9.4 \pm 4.3$ & $7.1 \pm 2.1$ & 0.1 \\
\hline nRBC (/100 WBCs) & $1262 \pm 695.9$ & $22.6 \pm 20.2$ & $<0.001$ \\
Corrected reticulocyte (\%) & $12.3 \pm 5.9$ & $3.5 \pm 1.0$ & $<0.001$ \\
\hline Serum ferritin* (ng/mL) & 3298.5 & 504.9 & 0.001 \\
ALT (U/L) & $(1420-5111)$ & $(328-926)$ & \\
\hline
\end{tabular}

SP, splenectomized; NSP, non-splenectomized; BMI, body mass index; Hb, hemoglobin; WBC, white blood cell; nRBC, nucleated red blood cell; ALT, alanine aminotransferase. *Data expressed as median (range).

Table 2. Pulmonary functions and $\mathrm{PaO}_{2}$, serum ferritin level between splenectomized and non-splenectomized $\mathrm{E} / \beta$-thalassemia patients (data are expressed as mean $\pm \mathrm{SD}$ ).

\begin{tabular}{|c|c|c|c|}
\hline & $\begin{array}{c}\mathrm{SP} \\
\mathrm{N}=13\end{array}$ & $\begin{array}{c}\text { NSP } \\
N=12\end{array}$ & $\mathbf{P}$ \\
\hline $\mathrm{FEV}_{1}(\%$ predicted $)$ & $62.2 \pm 14.4$ & $74.8 \pm 12.0$ & 0.028 \\
\hline FVC (\% predicted) & $66 \pm 15.0$ & $77.58 \pm 11.7$ & 0.043 \\
\hline $\mathrm{FEV}_{1} / \mathrm{FVC}$ & $84.6 \pm 5.3$ & $85.8 \pm 5.2$ & 0.568 \\
\hline $\mathrm{FEF}_{25-75 \%}(\%$ predicted $)$ & $62.3 \pm 20.2$ & $80.5 \pm 24.9$ & 0.057 \\
\hline TLC (\% predicted) & $67.5 \pm 9.3$ & $73.25 \pm 9.2$ & 0.136 \\
\hline RV (\% predicted) & $78 \pm 17$ & $64 \pm 15$ & 0.036 \\
\hline FRC (\% predicted) & $96 \pm 27.3$ & $102 \pm 29.2$ & 0.548 \\
\hline IC (L) & $1.05 \pm 0.3$ & $1.23 \pm 0.3$ & 0.181 \\
\hline IC (\% predicted) & $39.6 \pm 10.9$ & $45.6 \pm 11.2$ & 0.188 \\
\hline $\operatorname{ERV}(\mathrm{L})$ & $1.37 \pm 0.5$ & $1.69 \pm 0.7$ & 0.184 \\
\hline ERV (\% predicted) & $100 \pm 27.8$ & $122 \pm 35.7$ & 0.098 \\
\hline $\mathrm{DL}_{\mathrm{co}}(\mathrm{mL} / \mathrm{min} / \mathrm{mmHg})$ & $14.2 \pm 3.3$ & $16.9 \pm 6.6$ & 0.217 \\
\hline $\mathrm{DL}_{\mathrm{CO}}(\%$ predicted $)$ & $63.8 \pm 10.3$ & $73.9 \pm 22.0$ & 0.169 \\
\hline $\mathrm{DL}_{\mathrm{CO}}$ adjusted for $\mathrm{Hb}$ (\% predicted) & $136.2 \pm 26.8$ & $144.8+32.4$ & 0.475 \\
\hline $\mathrm{PaO}_{2}(\mathrm{mmHg})$ & $79.4 \pm 11.6$ & $98.8+6.2$ & $<0.001$ \\
\hline $\mathrm{P}(\mathrm{A}-\mathrm{a}) \mathrm{O}_{2}(\mathrm{mmHg})$ & $20.4 \pm 10.5$ & $6.8+3.3$ & $<0.001$ \\
\hline
\end{tabular}

SP, splenectomized; NSP, non-splenectomized; $\mathrm{FEV}_{1}$, forced expiratory volume; FVC, forced vital capacity; FEF, forced expiratory flow; TLC, total lung capacity; RV, residual volume; $\mathrm{FRC}$, functional residual capacity; IC, inspiratory capacity; $\mathrm{ERV}$, expiratory reserve volume; $\mathrm{DL}_{\mathrm{c}}$, diffusing capacity for carbon monoxide; $\mathrm{Hb}$, hemoglobin; $\mathrm{PaO}_{2}$, partial pressure of oxygen; $\mathrm{P}(\mathrm{A}-\mathrm{a}) \mathrm{O}_{2}$, alveolar-arterial partial pressure of oxygen difference. 
Serum ferritin levels in the SP group were significantly higher than those in the NSP group (3298.5 $\mathrm{ng} / \mathrm{mL}$; range $1420-5111 \mathrm{ng} / \mathrm{mL} v s$ $504.9 \mathrm{ng} / \mathrm{mL}$; range $328-926 \mathrm{ng} / \mathrm{mL}, \mathrm{P}=0.001$ ). There were inverse correlations between FVC and serum ferritin levels $(\mathrm{r}=-0.46, \mathrm{P}=0.02)$, and between $\mathrm{PaO}_{2}$ and serum ferritin levels $(\mathrm{r}=$ $-0.49, \mathrm{P}=0.013)$. Chest radiographs were available for review in 17 patients. Of these, extramedullary hematopoiesis was found in 9 SP and 1 NSP $(\mathrm{P}=0.018)$. Thalassemic bone changes were found in $11 \mathrm{SP}$ and 3 NSP $(\mathrm{P}=0.029)$. Cardiomegaly was present in $7 \mathrm{SP}$ and 2 NSP $(\mathrm{P}=0.335)$. Echocardiographic data could be obtained from 15 patients whereas PAP from RHC data was from 9 patients. $\mathrm{PH}$ was found in 7 SP. The SPAP and mean PAP values from RHC were $60.3 \pm 16.30 \mathrm{mmHg}$ and $37.4 \pm 10.15 \mathrm{mmHg}$, respectively. The eSPAP from echocardiography in this group was $41.5 \pm 7.6 \mathrm{mmHg}$. There were good correlations between eSPAP and SPAP $(\mathrm{r}=0.74, \mathrm{P}=0.034)$ and between eSPAP and mean PAP $(r=0.76$, $\mathrm{P}=0.03)$. Factors associated with $\mathrm{PH}$ in SP are shown in Table 3. Seven (54\%) SP who developed $\mathrm{PH}$ had a longer time interval between splenectomy and the onset of $\mathrm{PH}$ than those who did not $(17 \pm 4.9$ years vs $9.8 \pm 6.1$ years, $\mathrm{P}=0.04)$. SP with $\mathrm{PH}$ had greater $\mathrm{nRBC}$ count than those without $\mathrm{PH}(1673 \pm 536.82 / 100 \mathrm{WBCs}$ vs $782 \pm 403.93 / 100$ WBCs, $\mathrm{P}=0.013)$. Of the 9 patients who had RHC performed, no evidence of emboli was reported. The eSPAP was moderately correlated with $\mathrm{DL}_{\mathrm{CO}}(\mathrm{r}=-0.6, \mathrm{P}=0.04)$ but was not correlated with FVC $(\mathrm{r}=-0.38, \mathrm{P}=0.22)$, TLC $(\mathrm{r}=-0.4, \mathrm{P}=0.18)$, or $\mathrm{PaO}_{2}(\mathrm{r}=-0.12$, $\mathrm{P}=0.7)$. There were no significant correlations between SPAP determined by RHC and other parameters, including FVC $(\mathrm{r}=0.3, \mathrm{P}=0.2)$, TLC $(\mathrm{r}=0.3, \mathrm{P}=0.2), \mathrm{PaO}_{2}(\mathrm{r}=-0.5, \mathrm{P}=0.2)$, and $\mathrm{DL}_{\mathrm{C} 0}$ $(\mathrm{r}=-0.3, \mathrm{P}=0.4)$.

\section{Discussion}

Our results confirmed that RI was commonly found in both splenectomized and non-splenectomized E/ $\beta$-Thal patients. Moreover, we found a greater frequency of RI ( $84 \%$ of SP and $75 \%$ of NSP) than those previously reported up to $70 \%,{ }^{9}$ and a greater percentage of SP having more severe degree of RI and arterial hypoxemia, when compared to the NSP.

Although the exact mechanisms are unknown, there are possible mechanisms regarding the development of $\mathrm{RI}$ in $\mathrm{E} / \mathrm{\beta}$-Thal patients. As shown in the studies of Filosa et al. ${ }^{7}$ and Fung et al. ${ }^{8}$ older thalassemia patients with an average age of $19 \pm 1.4$ years had more RI than younger patients with average age of $10.8 \pm 1.7$ years and $15.7 \pm 1.1$ years did. Nevertheless, both SP and NSP in our study were older than those in the previous studies.

The reduction in lung volumes in $\mathrm{E} / \mathrm{\beta}$-Thal patients may also be explained by enlarged spleen and liver or by insufficient anatomical and functional development of the lungs during early life. ${ }^{5}$ Furthermore, an increase in vital capacity in patients following splenectomy has been reported. ${ }^{18}$ However, the RI in this study was unlikely to be owing to the effect of organomegaly because more severity of RI was found in the SP than in the NSP.

The relation between the reduction in lung volumes and the presence of iron overload secondary to the therapy has been raised. ${ }^{27}$ Iron deposition in the lung tissue can lead to free radical induced lung injury, regardless of serum ferritin levels. ${ }^{28}$ However, the previous autopsy study done by Witzleban and colleague ${ }^{29}$ showed no predilection of iron deposition to the lung (hemosiderosis). Our study showed other PFT parameters, e.g., normal or elevated $\mathrm{DL}_{\mathrm{C} 0}$ adjusted for hemoglobin values and preserved FRC and RV in the lung volumes subdivision, making the intrapulmonary causes of RI unlikely. As reported previously, the elevated $\mathrm{DL}_{\mathrm{C} 0}$ adjusted for hemoglobin is attributed to the effect of anemia in these patients. ${ }^{30}$ In this study, we found a greater proportion of SP who had more severe degree of RI and higher serum ferritin levels. This suggested more iron overload in these patients that might result from more frequent red blood cell transfusion to correct their anemia. Moreover, the presence of cardiomegaly secondary to high output heart failure in consequence of chronic anemia can reduce VA and subsequently an elevated $\mathrm{DL}_{\mathrm{CO}} \mathrm{NA}$ can occur in these patients. ${ }^{31}$

Interestingly, RI in SP in this study had a characteristic of preserved FRC, RV, and ERV accompanied by low IC, suggesting that the cause of RI in these patients might be related to respiratory muscle weakness or chest wall restriction rather than the intrapulmonary restriction caused by iron deposition in the lung tissue. This PFT finding was supported by the study of Hart and colleague ${ }^{32}$ showing that patients with combined inspiratory and expiratory muscle weakness had reduced TLC, $\mathrm{DL}_{\mathrm{C} 0}$, but had increased FRC and RV. We also speculated that the greater iron overload in SP could accelerate the production of reactive oxygen species which lead to muscular fatigue and eventually to the loss of skeletal muscle mass and impaired function. Reardon and colleague ${ }^{33}$ reported iron overloaded mice had elevated level of iron in skeletal muscle and increased serum ferritin. The level of oxidative stress product was higher compared with controls. Iron loading was found to reduce the skeletal muscle weight and function. In this study, the extramedullary hematopoiesis and thalassemic bone changes were found more frequently in the SP and might contribute to the chest wall restriction leading extrapulmonary RI. In contrast to the result of Hoyt ${ }^{12}$ and Keens ${ }^{15}$ in which the small airway obstruction was more common among their thalassemia patients, we found the small airway involvement to a lesser extent in only $12 \%$ of patients. All of whom with small airway involvement in our study also showed a combined restrictive impairment. This might be due to the difference in patients' age. Most thalassemia patients in both previous studies were pediatric population in which the average age was $6.8 \pm 0.6$ years old and patients in the study of Keens ${ }^{15}$ were on a hypertransfusion program. The authors proposed that the small airway obstruction could be due to iron deposition in the airways.

Arterial hypoxemia was found only in SP $(28 \%)$ in our study. Hypoxemia in these patients was associated with a widening in the

Table 3. Factors associated with development of pulmonary hypertension in splenectomized patients(data are expressed as mean $\pm \mathrm{SD}$ ).

\begin{tabular}{lccc} 
Factors & $\begin{array}{c}\mathrm{PH} \\
(\mathrm{n}=7)\end{array}$ & $\begin{array}{c}\mathrm{No} \mathrm{PH} \\
(\mathrm{n}=6)\end{array}$ & $\mathrm{P}$ \\
Age at entry (years) & $22.6 \pm 2.6$ & $20.8 \pm 3.9$ & 0.366 \\
Age at splenectomy (years) & $5.6 \pm 3.6$ & $10.7 \pm 7.8$ & 0.150 \\
\hline Time interval after splenectomy (years) & $17.0 \pm 4.9$ & $9.8 \pm 6.1$ & 0.04 \\
FVC (\% predicted) & $62.6 \pm 14.4$ & $70.0 \pm 15.9$ & 0.397 \\
\hline TLC (\% predicted) & $64.1 \pm 8.9$ & $71.5 \pm 8.7$ & 0.162 \\
DLCO adjusted for Hb (\% predicted) & $138.3 \pm 28.2$ & $133.8 \pm 27.3$ & 0.779 \\
\hline $\mathrm{PaO}_{2}, \mathrm{mmHg}$ & $78.3 \pm 13.8$ & $80.7 \pm 9.6$ & 0.729 \\
$\mathrm{P}(\mathrm{A}-\mathrm{a}) \mathrm{O}_{2}, \mathrm{mmHg}$ & $21.0 \pm 11.0$ & $19.7 \pm 10.8$ & 0.841 \\
\hline Ferritin*, (ng/mL) & 2598 & 3814 & 0.366 \\
& $(476-5375)$ & $(844-6174)$ & \\
$\mathrm{Hb}, \mathrm{g} / \mathrm{dL}$ & $5.9 \pm 0.9$ & $6.6 \pm 0.9$ & 0.204 \\
\hline $\mathrm{nRBC}(/ 100 \mathrm{WBC})$ & $1673 \pm 536.8$ & $782 \pm 403.9$ & 0.013 \\
\hline
\end{tabular}

PH, pulmonary hypertension; Hb, hemoglobin; nRBC, nucleated red blood cell. *Data expressed as median (range). 
difference between alveolar and arterial partial pressure of oxygen. However, the mechanism of hypoxemia is still unclear. We speculated that hypoxemia is a consequence of alterations in pulmonary microvasculature, endothelial dysfunction known to occur in these patients and not related to other pulmonary functions related to the lung mechanics. ${ }^{34}$ There were no significant correlations among any pulmonary function parameters, including $\mathrm{PaO}_{2}$ and $\mathrm{PAP}$ values except $\mathrm{DL}_{\mathrm{C} 0}$. Atichartakarn and colleague ${ }^{21}$ reported the PH in SP was due to increased pulmonary vascular resistance from pulmonary arteriopathy without evidence of emboli. Pathogenesis of such changes in pulmonary microvasculature was from chronic lowgrade hypercoagulable state and platelet activation after splenectomy. ${ }^{35} \mathrm{PH}$ was more prevalent in patients with a longer time interval between splenectomy and the onset of PH suggesting that $\mathrm{PH}$ was its late complication as supported by the study of Atichartakarn and colleague. ${ }^{21}$

The main limitations of our study were a retrospective nature and a small number of patients. However, we were able to demonstrate the different patterns of PFT abnormalities between SP and NSP and also the prevalence of $\mathrm{PH}$ following splenectomy. In conclusion, we found that $E / \beta$-Thal patients with previous splenectomy had a greater prevalence of more severe RI, arterial hypoxemia, and PH (a wellrecognized late complication after splenectomy). The more severe RI might be attributed to an extrapulmonary causes, namely combined abnormalities related to cardiomegaly, respiratory muscle weakness, or extramedullary hematopoiesis, whereas the arterial hypoxemia might be a consequence of pulmonary arteriopathy. Nevertheless, the degree of PH was neither correlated with the degree of abnormalities of PFT nor the hypoxemia.

\section{References}

1. Abu-Ekteish FM, Al-Rimawi HS, Al-Ali MK, Shehabi IM. Pulmonary function tests in children with beta-thalassemia major. Chron Respir Dis 2007;4:19-22.

2. Arora M, Chandra J, Suri JC, et al. Pulmonary function tests in beta thalassemia. Indian J Pediatr 2001;68:239-42.

3. Azarkeivan A, Mehrvar A, Pour HS, et al. Pulmonary function test in transfusiondependent beta-thalassemia patients. Pediatr Hematol Oncol 2008;25:598-606.

4. Carnelli V, D’Angelo E, Pecchiari M, et al. Pulmonary dysfunction in transfusiondependent patients with thalassemia major. Am J Respir Crit Care Med 2003;168:180-4.

5. Cooper DM, Mansell AL, Weiner MA, et al. Low lung capacity and hypoxemia in children with thalassemia major. Am Rev
Respir Dis 1980;121:639-46.

6. Factor JM, Pottipati SR, Rappoport I, et al. Pulmonary function abnormalities in thalassemia major and the role of iron overload. Am J Respir Crit Care Med 1994;149: 1570-4.

7. Filosa A, Esposito V, Meoli I, et al. Evidence of a restrictive spirometric pattern in older thalassemic patients. Respiration 2001;68:273-8.

8. Fung KP, Chow OK, So SY, Yuen PM. Pulmonary function in thalassemia major. $\mathrm{J}$ Pediatr 1987;111:534-7.

9. Grisaru D, Rachmilewitz EA, Mosseri M, et al. Cardiopulmonary assessment in betathalassemia major. Chest 1990;98:1138-42.

10. Jamal R, Baizura J, Hamidah A, et al. Abnormalities in lung function among multiply-transfused thalassemia patients: results from a thalassemia center in Malaysia. Southeast Asian J Trop Med Public Health 2005;36:265-9.

11. Tai DY, Wang YT, Lou J, et al. Lungs in thalassaemia major patients receiving regular transfusion. Eur Respir J 1996;9:1389-94.

12. Hoyt RW, Scarpa N, Wilmott RW, et al. Pulmonary function abnormalities in homozygous beta-thalassemia. J Pediatr 1986;109:452-5.

13. Piatti G, Allegra L, Ambrosetti U, et al. Betathalassemia and pulmonary function. Haematologica 1999;84:804-8.

14. Piatti G, Allegra L, Fasano V, et al. Lung function in beta-thalassemia patients: a longitudinal study. Acta Haematol 2006;116: 25-9.

15. Keens TG, O'Neal MH, Ortega JA, et al. Pulmonary function abnormalities in thalassemia patients on a hypertransfusion program. Pediatrics 1980;65:1013-7.

16. Bacalo A, Kivity S, Heno N, et al. Blood transfusion and lung function in children with thalassemia major. Chest 1992;101: 362-5.

17. Li AM, Chan D, Li CK, et al. Respiratory function in patients with thalassaemia major: relation with iron overload. Arch Dis Child 2002;87:328-30.

18. Grant GP, Mansell AL, Graziano JH, Mellins RB. The effect of transfusion on lung capacity, diffusing capacity, and arterial oxygen saturation in patients with thalassemia major. Pediatr Res 1986;20:20-3.

19. Aessopos A, Farmakis D. Pulmonary hypertension in beta-thalassemia. Ann N Y Acad Sci 2005;1054:342-9.

20. Aessopos A, Stamatelos G, Skoumas V, et al. Pulmonary hypertension and right heart failure in patients with beta-thalassemia intermedia. Chest 1995;107:50-3.

21. Atichartakarn V, Likittanasombat K, Chuncharunee $S$, et al. Pulmonary arterial hypertension in previously splenectomized patients with beta-thalassemic disorders.
Int J Hematol 2003;78:139-45.

22. Crapo RO, Morris AH, Gardner RM. Reference spirometric values using techniques and equipment that meet ATS recommendations. Am Rev Respir Dis 1981; 123:659-64.

23. Crapo RO, Morris AH, Gardner RM. Reference values for pulmonary tissue volume, membrane diffusing capacity, and pulmonary capillary blood volume. Bull Eur Physiopathol Respir 1982;18:893-9.

24. Pfaff JK, Morgan WJ. Pulmonary function in infants and children. Pediatr Clin North Am 1994;41:401-23.

25. Janda S, Shahidi N, Gin K, Swiston J. Diagnostic accuracy of echocardiography for pulmonary hypertension: a systematic review and meta-analysis. Heart 2011;97:612-22.

26. Galie N, Hoeper MM, Humbert M, et al. Guidelines for the diagnosis and treatment of pulmonary hypertension. Eur Respir $\mathrm{J}$ 2009;34:1219-63.

27. Landing BH, Nadorra R, Hyman CB, Ortega JA. Pulmonary lesions of thalassemia major. Perspect Pediatr Pathol 1987;11:8296.

28. Luyt DK, Richards GA, Roode $\mathrm{H}$, et al. Thalassemia: lung function with reference to iron studies and reactive oxidant status. Pediatr Hematol Oncol 1993;10:13-23.

29. Witzleben CL, Wyatt JP. The effect of long survival on the pathology of thalassaemia major. J Pathol Bacteriol 1961;82:1-12.

30. Marrades RM, Diaz 0, Roca J, et al. Adjustment of DLCO for hemoglobin concentration. Am J Respir Crit Care Med 1997; 155:236-41.

31. Agostoni P, Cattadori G, Guazzi M, et al. Cardiomegaly as a possible cause of lung dysfunction in patients with heart failure. Am Heart J 2000;140:e24.

32. Hart N, Cramer D, Ward SP, et al. Effect of pattern and severity of respiratory muscle weakness on carbon monoxide gas transfer and lung volumes. Eur Respir J 2002;20: 996-1002.

33. Reardon TF, Allen DG. Iron injections in mice increase skeletal muscle iron content, induce oxidative stress and reduce exercise performance. Exp Physiol 2009;94:720-30.

34. Aessopos A, Farmakis D, Tsironi M, et al. Endothelial function and arterial stiffness in sickle-thalassemia patients. Atherosclerosis 2007;191:427-32.

35. Atichartakarn V, Chuncharunee S, Chandanamattha $\mathrm{P}$, et al. Correction of hypercoagulability and amelioration of pulmonary arterial hypertension by chronic blood transfusion in an asplenic hemoglobin E/beta-thalassemia patient. Blood 2004;103:2844-6. 